\title{
Impacts of land use change and climate variations on annual inflow into the Miyun Reservoir, Beijing, China
}

\author{
Jiangkun Zheng ${ }^{1,3}$, Ge Sun ${ }^{2}$, Wenhong $\mathrm{Li}^{3}$, Xinxiao Yu ${ }^{4}$, Chi Zhang ${ }^{3}$, Yuanbo Gong ${ }^{1}$, and Lihua Tu ${ }^{1}$ \\ ${ }^{1}$ College of Forestry, Sichuan Agricultural University, Chengdu, Sichuan, 611130, China \\ ${ }^{2}$ Eastern Forest Environmental Threat Assessment Center, USDA Forest Service, 920 Main Campus, Venture II, Suite 300, \\ Raleigh, NC 27606, USA \\ ${ }^{3}$ Earth and Ocean Sciences, Nicholas School of the Environment, Duke University, Durham, NC 27708, USA \\ ${ }^{4}$ School of Soil and Water Conservation, Beijing Forestry University, Beijing, 100083, China \\ Correspondence to: Jiangkun Zheng (jiangkunzheng@126.com)
}

Received: 27 June 2015 - Published in Hydrol. Earth Syst. Sci. Discuss.: 11 August 2015

Revised: 31 January 2016 - Accepted: 4 April 2016 - Published: 22 April 2016

\begin{abstract}
The Miyun Reservoir, the only surface water source for Beijing city, has experienced water supply decline in recent decades. Previous studies suggest that both land use change and climate contribute to the changes of water supply in this critical watershed. However, the specific causes of the decline in the Miyun Reservoir are debatable under a non-stationary climate in the past 4 decades. The central objective of this study was to quantify the separate and collective contributions of land use change and climate variability to the decreasing inflow into the Miyun Reservoir during 1961-2008. Different from previous studies on this watershed, we used a comprehensive approach to quantify the timing of changes in hydrology and associated environmental variables using the long-term historical hydrometeorology and remote-sensing-based land use records. To effectively quantify the different impacts of the climate variation and land use change on streamflow during different subperiods, an annual water balance model (AWB), the climate elasticity model (CEM), and a rainfall-runoff model (RRM) were employed to conduct attribution analysis synthetically. We found a significant $(p<0.01)$ decrease in annual streamflow, a significant positive trend in annual potential evapotranspiration $(p<0.01)$, and an insignificant $(p>0.1)$ negative trend in annual precipitation during 1961-2008. We identified two streamflow breakpoints, 1983 and 1999, by the sequential Mann-Kendall test and double-mass curve. Climate variability alone did not explain the decrease in inflow to the Miyun Reservoir. Reduction of water yield was closely related to increase in actual evapotranspiration due to the ex-
\end{abstract}

pansion of forestland and reduction in cropland and grassland, and was likely exacerbated by increased water consumption for domestic and industrial uses in the basin. The contribution to the observed streamflow decline from land use change fell from 64-92\% during 1984-1999 to 36-58 \% during 2000-2008, whereas the contribution from climate variation climbed from 8-36\% during the 1984-1999 to 42$64 \%$ during 2000-2008. Model uncertainty analysis further demonstrated that climate warming played a dominant role in streamflow reduction in the most recent decade (i.e., 2000s). We conclude that future climate change and variability will further challenge the water supply capacity of the Miyun Reservoir to meet water demand. A comprehensive watershed management strategy needs to consider the climate variations besides vegetation management in the study basin.

\section{Introduction}

Land use change and climate variations are two main factors directly affecting the watershed hydrological cycle. Land use change influences watershed water yield by changing canopy interception, soil properties, biophysical factors affecting evapotranspiration, and groundwater use, whilst climate variations alter precipitation, air temperature, humidity, plant growth, and consequently the hydrologic balances (Baker and Miller, 2013; Wang et al., 2013). Meanwhile, interactions of land use change and climate variations are complex, and understanding the individual effects on watershed 
water yield is of great importance for land use planning and water resource management (Zheng et al., 2013). To optimize watershed management, it is important to assess hydrological impacts of climate variations and land use change separately and collectively (Mango et al., 2011). Artificial neural networks and the Soil Conservation Service curve number were employed to evaluate the effect of land use change on daily streamflows in western Georgia, USA (Isik et al., 2013). The Soil and Water Assessment Tool (SWAT) was also applied to assess impacts of land use and climate change on hydrologic processes in a coastal Alabama watershed in USA (Wang et al., 2014) and the Hoeya River basin, South Korea (Kim et al., 2013). A clear understanding of the driving factors benefits both hydrological model development and hydrologic assessment of global change (Wang et al., 2013). Due to the nonlinearity of streamflow response in the synchronous evolution of driving forces, it is challenging to disentangle the integrative effects of climate forcing and basin characteristics (Risbey and Entekhabi, 1996; Beguería et al., 2003; Arabi et al., 2007; Morán-Tejeda et al., 2010). Many methods have been developed for isolating the effect of land use change from climate variations on regional hydrology. These methods include the paired catchment approach (Brown et al., 2005; Zégre et al., 2010), statistical methods (Costa et al., 2003; Sun et al., 2006; Petchprayoon et al., 2010), and a hydrological model (Haverkamp et al., 2005; Mao and Cherkauer, 2009; Baker and Miller, 2013). Raymond et al. (2008) suggested that land use change and management have been more important than climate variation to increase riverine water export from the Mississippi River over the past 50 years. However, other studies considered climate change as a dominant cause of annual water yield change (Aguado et al., 1992; Christensen et al., 2004; Barnett et al., 2005; Sun et al., 2013). Thus, both land use change and climatic variation should be considered to detect causes of hydrologic change at the same time.

The Miyun Reservoir provides $70 \%$ of the total water supply for Beijing and is the only source of surface water supply for the severely water-stressed megacity with a population of 20 million (Tang et al., 2011). Over the past half-century, streamflow into the Miyun Reservoir has shrunk drastically. Mean annual inflow into the Miyun Reservoir declined from $88.2 \mathrm{~m}^{3} \mathrm{~s}^{-1}$ in the $1950 \mathrm{~s}$ to $15.8 \mathrm{~m}^{3} \mathrm{~s}^{-1}$ in the $1980 \mathrm{~s}$ (Gao et al., 2002). Meanwhile, population in Beijing increased from 2.8 million in 1953 to 20 million in the 2000s (Liu et al., 2003). The local water consumption in the catchment is believed to be the main driving factor in addition to climate (Ma et al., 2010). Now, 18 reservoirs have been built in the catchment with a total storing capacity of 0.214 billion $\mathrm{m}^{3}$ (Li and $\mathrm{Li}, 2008$ ). The contradiction between increasing water demand and water shortage constrains economic and social development of the region. Therefore, water resource assessment is extremely important to develop effective management strategies.
A few studies have tried to isolate hydrological impacts of land use change from climate change on streamflow in the Miyun Reservoir catchment (MYRC) (Wang et al., 2009, 2013; Xu et al., 2009; Ma et al., 2010; Zhan et al., 2011; Bao et al., 2012a). However, conclusions varied significantly. For example, Wang et al. (2009) and Ma et al. (2010) suggested that climate impact separately accounted for about 33 and $55 \%$ of the decrease in reservoir inflow using the distributed time-variant gain model and geomorphology-based hydrological model, respectively. The discrepancies are mainly caused by assessment methodology due to parameter uncertainty (Shen et al., 2012), diversities of structural complexity (Velázquez et al., 2013), and inconsistencies of the evaluation period (López-Moreno et al., 2011). It remains a grand challenge in watershed hydrology (especially for large basins) to seperate the hydrological effect of land use and from climate change and variability. Hence, Wei et al. (2013) indicate that a combination of two or three methods would be a robust research strategy to assess hydrological effect within a certain range.

This study attempts to (1) detect the trend and break points of streamflow series for the period from 1961 to 2008, (2) explore an integrated approach to evaluate phased effects of climate and land use change on the inflow into the Miyun Reservoir, and (3) provide suggestions to watershed management for the studied watershed.

In this research, the relative contributions of land use change and climate variability to changes of the annual streamflow into the Miyun Reservoir were quantified using an annual water balance model based on Zhang et al. (2001), the climate elasticity model (CEM; Sankarasubramanian et al., 2001), and rainfall-runoff models (RRMs; Jones et al., 2006) for understanding water cycles and balance in the study area. Unlike previous studies that use one evaluation period, this study uses two evaluation periods to assess hydrological impact of land use change and climate variation over time. Meanwhile, three different hydrological models were combined to assess hydrological effect in each evaluation period.

\section{Materials and methods}

\subsection{Catchment characteristic}

The Miyun Reservoir, located about $100 \mathrm{~km}$ to the north of downtown Beijing, was built in 1960. The reservoir, which receives water from the Chao River and the Bai River, has a total storage capacity of approximately 4.4 billion $\mathrm{m}^{3}$, enough to supply more than half of the water supply for Beijing city (Dong and $\mathrm{Li}, 2006$ ). The drainage area is about $15380 \mathrm{~km}^{2}\left(115^{\circ} 25^{\prime}-117^{\circ} 33^{\prime} \mathrm{E}, 40^{\circ} 19^{\prime}-41^{\circ} 31^{\prime} \mathrm{N}\right)$, occupying nearly $90 \%$ of the Chaobai River basin area (Fig. 1). The local climate is characterized as temperate monsoon and semi-arid (Xu et al., 2009). The MYRC drains nine counties 


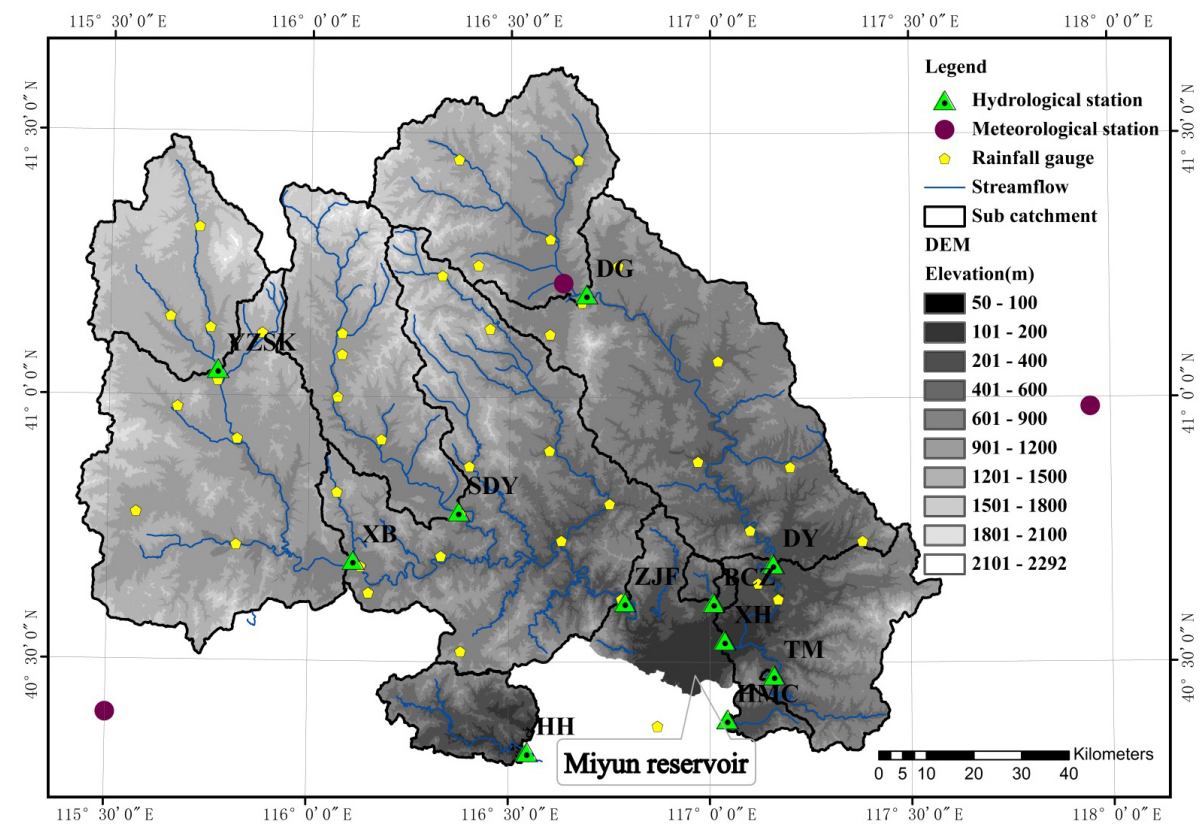

Figure 1. Information of the Miyun Reservoir catchment and sub-catchments including YZSK (Yunzhoushuiku, $\left.1193 \mathrm{~km}^{2}\right), \mathrm{XB}(\mathrm{Xiabao}$, $3960 \mathrm{~km}^{2}$ ), SDY (Sandaoying, $1536 \mathrm{~km}^{2}$ ), ZJF (Zhangjiafen, $\left.8762 \mathrm{~km}^{2}\right)$, DG (Dage, $\left.1660 \mathrm{~km}^{2}\right)$, DY (Daiying, $\left.4634 \mathrm{~km}{ }^{2}\right)$, XH $($ Xiahui, $5891 \mathrm{~km}^{2}$ ), HH (Huaihe, $486 \mathrm{~km}^{2}$ ), HMC (Hongmenchuan, $111 \mathrm{~km}^{2}$ ), BCZ (Banchengzi, $65 \mathrm{~km}^{2}$ ), and TM (Tumen, $3 \mathrm{~km}{ }^{2}$ ).

of Hebei Province and three counties of Beijing city. The total landmass of Chicheng, Guyuan, Luanping, and Fengning counties in Hebei Province accounts for $77 \%$ of the whole catchment area (Wang, 2010). The population of the four counties increased from 0.95 million during 1961-1983 to 1.18 million during 1984-1999, and further to 1.23 million during 2000-2008 (Fig. 2). Land use maps were converted from the 1:100000 land use map of China, which was obtained from the Resources and Environment Data Center of CAS (http://www.resdc.cn/dataResource/dataResource. asp). Based on data availability and model building, land use maps of sub-catchments were used including Yuzhoushuiku (YZSK), Xiabao (XB), Sandaoying (SDY), Zhangjiafen (ZJF), Dage (DG), Daiying (DY), and Xiahui $(\mathrm{XH})$ in 1978, 1988, 1998, and 2008; Huaih (HH), Hongmenchuan (HMC), and Banchengzi (BCZ) in 1990, 1995, 2000, and 2005; and Tumen (TM) in 2000 and 2005 (Fig. 1). The land use was regrouped into six categories: water, bare land, forestland, cropland, grassland, and residential area.

\subsection{Hydrometeorological data}

Daily precipitation data recorded at 37 rainfall gauges and daily discharge data of 11 hydrological stations were obtained from "Hydrological Year Book" by the China Hydrological Bureau. Daily meteorological data for the period of 1961-2008 including precipitation, air temperature (maximum, minimum, and mean), wind speed, relative humidity, and sunshine hours of seven meteorological stations (Zhang- bei, Fengning, Weichang, Zhangjiakou, Huailai, Chengde, and Beijing) were obtained from the China Administration of Meteorology. Daily $E_{\mathrm{p}}$ was calculated using the Hamon method (Hamon, 1963; Lu et al., 2005) as described in Sect. 2.4.1. All the hydrometeorological data were processed in accordance with international standards. Abnormal data were replaced by the values obtained from kriging interpolation using nearby weather stations. Mean hydrometeorological data for the entire catchment were all obtained by the kriging interpolation method in ArcGIS 9.3.

Average monthly temperatures from November to February were below $0^{\circ} \mathrm{C}$. Minimum monthly temperature in January was lowest at $-15^{\circ}$, and maximum monthly temperature in July was highest at $29^{\circ}$. Precipitation $(P)$ in summer (June, July, and August) accounted for $68 \%$ of annual total precipitation. In comparison, summer potential evapotranspiration $\left(E_{\mathrm{p}}\right)$ accounted for $48 \%$ of annual totals (Fig. 3).

\subsection{Detecting the break points of streamflow time series}

Both the double-mass curve (Searcy and Hardison, 1960) and the sequential version of the Mann-Kendall test (Mann, 1945; Sneyers, 1975) were applied to detect the break points. The double-mass curve represents two cumulative records. A break in the curve indicates a change in the relationship between the two records that may be caused by the processing of the data (Wigbout, 1973). A non-parametric test method, the sequential version of the Mann-Kendall test, is used to detect the change point of hydrological data series: 


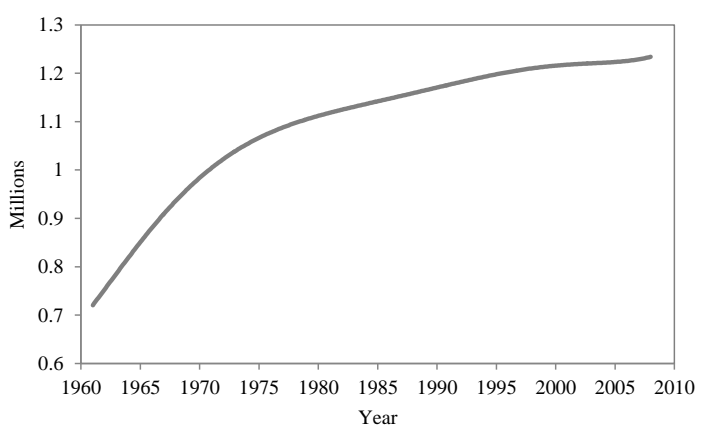

Figure 2. Change in the population of four main counties located in Hebei Province from 1961 to 2007.

$S_{k}=\sum_{i=1}^{k} r_{i}(k=2,3, \ldots, n)$,

where $r_{i}$ is as follows:

$r_{i}=\left\{\begin{array}{l}+1\left(x_{i}>x_{j}\right) \\ 0\left(x_{i} \leq x_{j}\right)\end{array} \quad(j=1,2, \ldots, i)\right.$.

For each comparison, the number of cases $x_{i}>x_{j}$ is counted and denoted by $r_{i}$. It is assumed that the statistic sequential values are random and independent. Then statistic variance $\left(\mathrm{UF}_{k}\right)$ is defined as follows:

$\mathrm{UF}_{k}=\frac{\left[s_{k}-E\left(s_{k}\right)\right]}{\sqrt{\operatorname{Var}\left(s_{k}\right)}}(k=1,2, \ldots, n)$,

$E\left(s_{k}\right)=\frac{n(n+1)}{4}$,

$\operatorname{Var}\left(s_{k}\right)=\frac{n(n+1)(2 n+5)}{72}$,

where $E\left(s_{k}\right)$ and $\operatorname{Var}\left(s_{k}\right)$ are mean and variance of $s_{k}$, respectively. Statistic variance $\mathrm{UF}_{k}$ is calculated as the forward data series $\left(\mathrm{UF}_{1}=0\right)$. The backward sequence $\mathrm{UB}_{k}$ is calculated using the same equation but in the reverse data series. A null hypothesis is accepted if the critical value $\left(u_{0.05}\right)$ lies within \pm 1.96 at a significance level $(\alpha=0.05)$. The positive $\mathrm{UF}_{k}$ denotes an upward trend, while the reverse series denotes a downward trend. When the value of $\mathrm{UF}_{k}$ exceeds the critical value $\left(u_{0.05}\right)$, it demonstrates an upward or downward trend significantly. If there are intersections of $\mathrm{UF}_{k}$ and $\mathrm{UB}_{k}$ lines in the range of critical value $\left(u_{0.05}\right)$, the first cross point is the break point.

\subsection{Hydrological models for attribution analysis}

In this study, climate variations primarily refer to the changes of $P$ and $E_{\mathrm{p}}$. Due to difficulty in quantitatively describing anthropogenic effects including water withdrawal and water consumption, land use change is used as the residuals affecting streamflow $(Q)$ in addition to climate variations following Stohlgren et al. (1998) and Ma et al. (2010). Three

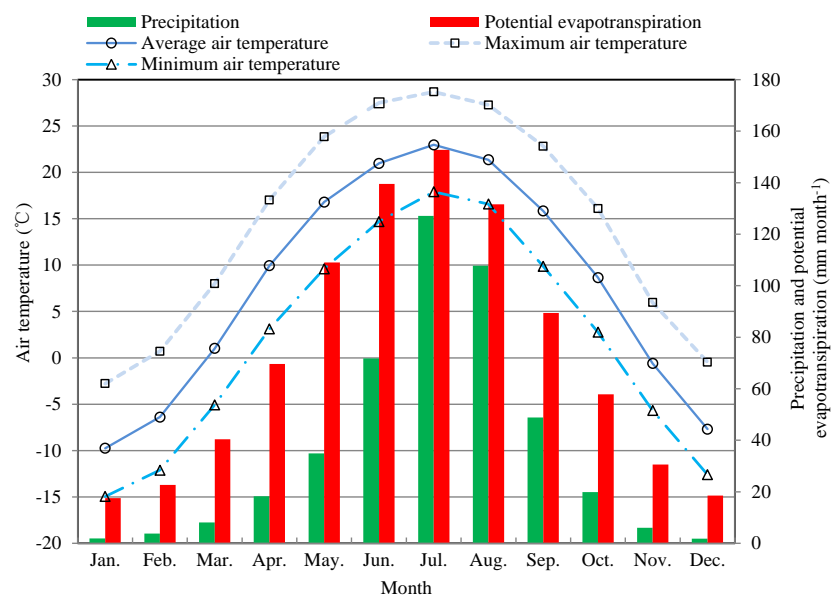

Figure 3. Monthly average precipitation, potential evapotranspiration, and air temperature during 1961-2008 in the Miyun Reservoir catchment.

models were built to provide a comprehensive evaluation on streamflow decreases in the MYRC.

\subsubsection{Annual water balance model (AWB)}

To detect the influence of land use change on $Q$, a model was developed based on the sensitivity of land use change to actual evapotranspiration $\left(E_{\mathrm{a}}\right)$ (Zhang et al., 2001). Formulas were described as follows:

$Q=P-\mathrm{AET} \pm \Delta \delta$,

$E_{\mathrm{a}}=\frac{1+\omega \frac{E_{\mathrm{p}}}{P}}{1+\omega \frac{E_{\mathrm{p}}}{P}+\frac{P}{E_{\mathrm{p}}}} \times P$,

$E_{\mathrm{a}(\mathrm{tot})}=\sum_{i=1}^{n}\left(E_{\mathrm{a}(i)} \times f_{i}\right)$,

$E_{\mathrm{p}}=0.1651 D V_{\mathrm{d}} K\left(E_{\mathrm{p}}=0\right.$ when $\left.T<0\right)$,

$V_{\mathrm{d}}=216.7 V_{\mathrm{s}} /(T+273.3)$,

$V_{\mathrm{s}}=6.108 \times \exp (17.26939 T /(T+273.3))$,

where $\delta\left(\mathrm{mm} \mathrm{yr}^{-1}\right)$ is the water storage change of the watershed which can be neglected on long time averages (Donohue et al., 2010). On a meso-scale, the watershed annual $Q$ $\left(\mathrm{mm} \mathrm{yr}^{-1}\right)$ can be estimated as the difference between the $P\left(\mathrm{~mm} \mathrm{yr}^{-1}\right)$ input and the $E_{\mathrm{a}}\left(\mathrm{mm} \mathrm{yr}^{-1}\right)$ output (Sun et al., 2005). $\omega$ is the plant-available water coefficient that varies in soil water use for transpiration. For the MYRC, $\omega$ values of different land use, as a key indicator, were estimated by a trial-and-error approach with increments of 0.1 using a computer program. $f_{i}$ is the percentage of land use area, in which $i$ represents diverse landscapes: forestland, grassland, cropland, water area, residential area, and bare area. $E_{\mathrm{a}(\mathrm{tot})}$ is the sum of $E_{\mathrm{a}(i)} . D$ is the day length (h). $V_{\mathrm{d}}$ is saturated vapor density at the daily average temperature $\left(\mathrm{g} \mathrm{m}^{-3}\right) ; K$ is 
the correction factor. $T$ is the daily average temperature $\left(^{\circ}\right)$. $V_{\mathrm{S}}$ is the saturated vapor under a certain temperature (mbar).

\subsubsection{The climate elasticity model}

To quantitatively evaluate the influence of climate variation on streamflow, CEM was built. The CEM defines the proportional change of streamflow divided by the proportional change in a climate variable such as precipitation (Ma et al., 2010). The model was first developed by Schaake and Waggoner (1990) to evaluate the sensitivity of streamflow to climate changes and then employed widely to assess the climate variability impact (Sankarasubramanian et al., 2001; Jones et al., 2006; Fu et al., 2007; Bao et al., 2012b):

$\frac{Q_{i}}{\overline{Q_{0}}}=\varepsilon_{1} \frac{P_{i}}{\bar{P}}+\varepsilon_{2} \frac{\operatorname{PET}_{i}}{\overline{\mathrm{PET}}} \frac{\Delta Q_{i}}{\overline{Q_{0}}}=\varepsilon_{1} \frac{\Delta P_{i}}{\bar{P}}+\varepsilon_{2} \frac{\Delta E_{\mathrm{p}(i)}}{\overline{E_{\mathrm{p}}}}$,

$d \bar{Q}_{\mathrm{clim}}=\overline{Q_{\mathrm{e}} Q_{0}}$,

$d \bar{Q}_{\text {land }}=\overline{O_{\mathrm{e}} Q_{\mathrm{e}}}$,

$d \bar{Q}_{\mathrm{tot}}=d \bar{Q}_{\mathrm{clim}}+d \bar{Q}_{\mathrm{land}}$,

where $\varepsilon_{1}$ and $\varepsilon_{2}$ are elasticity coefficients for $P\left(\mathrm{~mm} \mathrm{yr}^{-1}\right)$ and $E_{\mathrm{o}}\left(\mathrm{mm} \mathrm{yr}^{-1}\right)$, respectively, which are estimated by least-square estimation with Matlab7.0. $\overline{Q_{0}}\left(\mathrm{~mm} \mathrm{yr}^{-1}\right), \bar{P}$ $\left(\mathrm{mm} \mathrm{yr}^{-1}\right)$, and $\overline{E_{\mathrm{p}}}\left(\mathrm{mm} \mathrm{yr}^{-1}\right)$ refer to the mean annual $Q, P$, and $E_{\mathrm{p}}$ in the reference period, respectively. $\Delta P_{i}$ and $\Delta E_{\mathrm{p}(i)}$ are the change of annual $P$ and $E_{\mathrm{p}}$ compared to $\bar{P}$ and $\overline{E_{\mathrm{p}}}$, respectively. Annual $Q\left(\mathrm{~mm} \mathrm{yr}^{-1}\right)$ for the period of $1984-$ 1999 and 2000-2008 can be derived from Eq. (12) and calculated into mean value $\left(\overline{Q_{\mathrm{e}}}\right) \cdot d \bar{Q}_{\text {clim }}$ is the average change in $Q$ caused by climate impact. $d \bar{Q}_{\text {land }}$ is the average change in $Q$ caused by land use change, and $d \bar{Q}_{\text {tot }}$ is the average change in $Q$ between the reference period and evaluation period. $\overline{O_{\mathrm{e}}}$ and $\overline{Q_{\mathrm{e}}}$ are the average annual $Q$ observed and simulated during the evaluation periods, respectively.

\subsubsection{Rainfall-runoff model}

In addition to the CEM method discussed in SEct. 2.4.2, the impact of climate variability on streamflow was also estimated using the following empirical rainfall-runoff models (Jones et al., 2006; Li et al., 2007).

$Q_{i}=a+b P_{i}\left(\sigma_{i}^{2}\right)^{c}$

$d \bar{Q}_{\mathrm{clim}}=\overline{Q_{\mathrm{e}} Q_{\mathrm{r}}}$

Here, $Q_{i}\left(\mathrm{~mm} \mathrm{yr}^{-1}\right)$ and $P_{i}\left(\mathrm{~mm} \mathrm{yr}^{-1}\right)$ are the annual observed streamflow and precipitation, respectively. $\sigma_{i}^{2}$ is the variance of the monthly precipitation; $a, b$, and $c$ are constants determined by hydrometeorological data in the reference period. $\overline{Q_{\mathrm{e}}}\left(\mathrm{mm} \mathrm{yr}^{-1}\right)$ and $\overline{Q_{\mathrm{r}}}\left(\mathrm{mm} \mathrm{yr}^{-1}\right)$ are the simulated mean annual streamflow during the evaluation period and reference period, respectively.

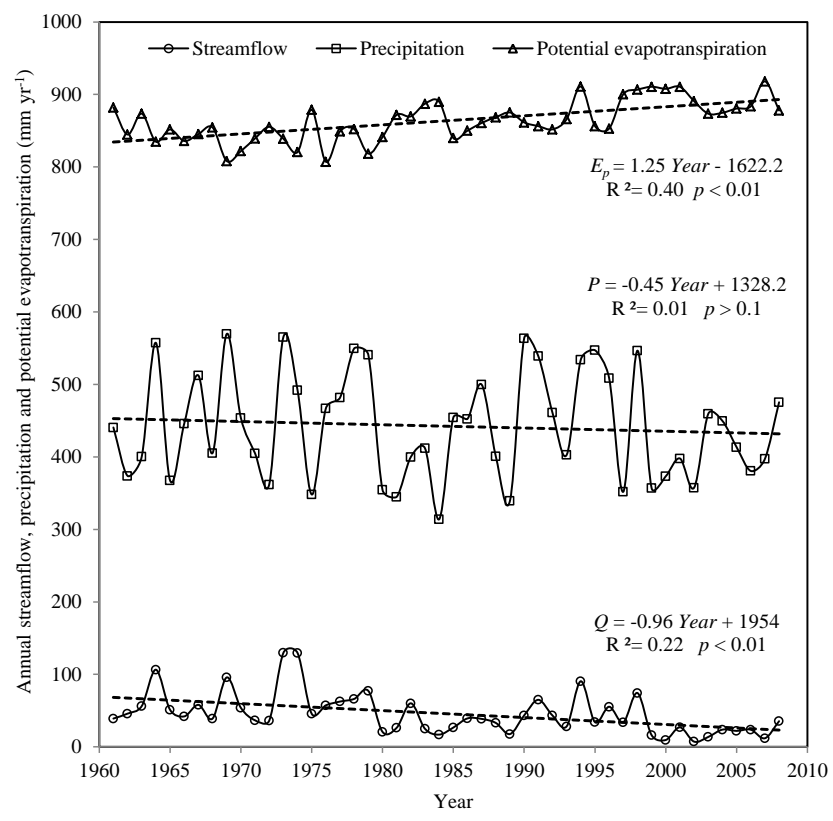

Figure 4. Evolution of streamflow $(Q)$, precipitation $(P)$, and potential evapotranspiration $\left(E_{\mathrm{p}}\right)$ of the Miyun Reservoir catchment over 1961-2008. The dashed lines are the fitted linear trend for variables.

\section{Results}

\subsection{Evolution and break points of annual streamflow series}

As described in Fig. 4, a significant decreasing trend at the rate of $0.96 \mathrm{~mm} \mathrm{yr}^{-1}$ was observed for annual streamflow during 1961-2008 ( $p<0.01)$. Simultaneously, $E_{\mathrm{p}}$ increased by $1.25 \mathrm{~mm} \mathrm{yr}^{-1}$ significantly $(p<0.01)$, and precipitation decreased by $0.45 \mathrm{~mm} \mathrm{yr}^{-1}$ insignificantly $(p>0.1)$ (Fig. 4). In the Chao River basin and Bai River basin, break points occurred in different years according to different methods. Using the ordered clustering analysis method (Xie et al., 2005), one break point at 1979 was detected in the runoff record in the river basins (Wang et al., 2009). Yang and Tian (2009) found that abrupt changes in runoff occurred in 1983 and 1980 for the Chao River basin and Bai River basin, respectively, based on the sequential Mann-Kendall test. Owing to significantly increasing direct water abstraction from upstream of the reservoir since 1984, two subperiods, one from 1956 to 1983 and the other from 1984 to 2005, were detected for the Chao and Bai River basins (Ma et al., 2010). Tang et al. (2011) noted that soil conservation practice positively affected the intensified reduction of streamflow after 1999. In this study, the year 1984, as intersection point of the $\mathrm{UF}_{k}$ and $\mathrm{UB}_{k}$ curves inside the dotted lines, was the break point. In addition, changes in streamflow from 2000 to 2008 were more significant because points of the curves fall outside the dotted lines (Fig. 5). Further- 


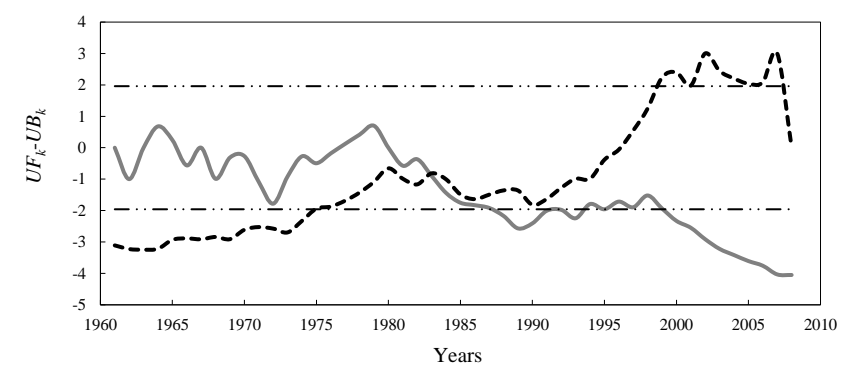

Figure 5. The sequential Mann-Kendall test for annual streamflow in the Miyun Reservoir catchment with forward-trend $\mathrm{UF}_{k}$ (solid line) and backward-trend $\mathrm{UB}_{k}$ (dotted line). Dashed bold horizontal lines represent critical values at the $95 \%$ confidence level.

more, the double-mass curve was also used to divide annual streamflow series into three phases (Fig. 6). Combining sequential Mann-Kendall test analysis with the double-mass curve test, we determined the reference period (1961-1983), the evaluation period I (1984-1999), and the evaluation period II (2000-2008) in the MYRC.

\subsection{AWB model}

A total of 41 sub-catchments with different land use composition were used to build the model. According to plantavailable water coefficient $w$ of different land use in the AWB model, the catchments were composed of forestland, grassland/cropland, water area, and residential/bare area. Forestland accounts for more than $50 \%$ of the whole area in the DG, DY, XH, YZSK, SDY, XB, and ZJF catchments; more than $80 \%$ of the total landmass in the BCZ, HMC, and $\mathrm{HH}$ watersheds; and $100 \%$ of total area in the TM catchment (Fig. 7). The model was calibrated with the data prior to 2001 and was validated with the data after 2001 (Fig. 8). The range of $w$ values was determined to be $[0,3]$ for forestland, $[0,2]$ for grassland/cropland, and $[0,1]$ for residential area/bare area. The $E_{\mathrm{a}}$ of water area was assumed to be smaller between $P$ and $E_{\mathrm{p}}$. Based on the method of trial and error, $w$ values of grassland/farmland, forestland, and residential area/bare area were identified as $1.5,2.8$, and 0 during the calibrated period, respectively. When the average annual water balance residual $E_{\mathrm{a}}=P-Q$ was compared with that estimated using Eqs. (7) and (8), the determination coefficients were 0.803 and 0.783 during calibration period and validation period, respectively (Fig. 8).

Compared to the reference period (1961-1983), annual observed streamflow for 1984-1999 and 2000-2008 reduced by 18.1 and $39.7 \mathrm{~mm}$, respectively. Using the land use data in 1988, the model was applied to evaluation periods. The difference of observed value and simulated value represented the impacts of land use change on inflow declines. As shown in Table $1, d \bar{Q}_{\text {land }}$ was -11.5 and $-19.6 \mathrm{~mm}$, which contributed 64 and $49 \%$ of $d \bar{Q}_{\text {tot }}$ for evaluation period I and II, respectively.

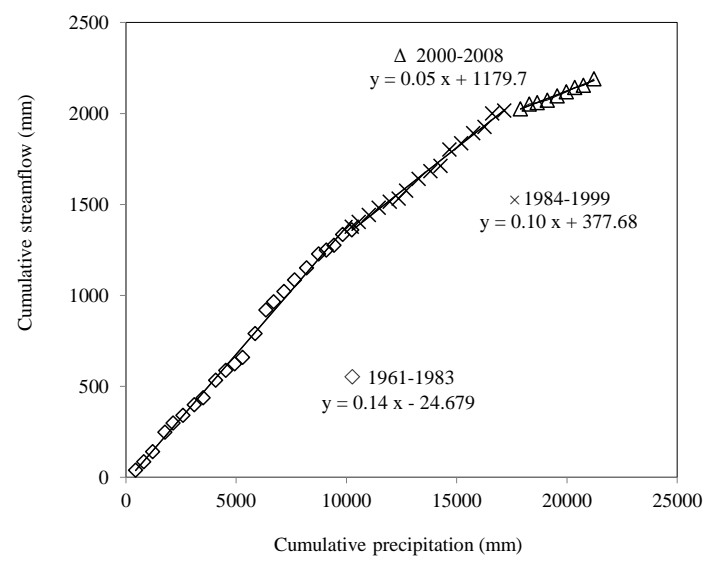

Figure 6. The double-mass curve showing the relations between cumulative streamflow and cumulative precipitation for the Miyun Reservoir catchment (1961-2008).

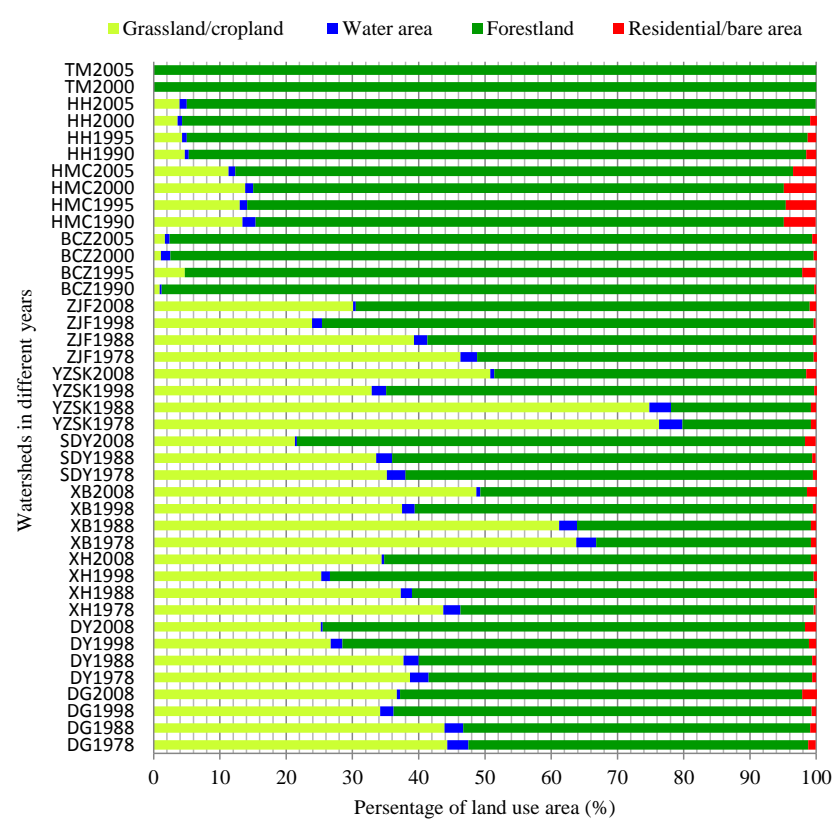

Figure 7. Land use composition of watersheds in different year used for annual water balance model building. For example, DG1978 refers to the Dage watershed in 1978. Data prior to 2001 were used for the model calibration. Data after 2001 were used for the model validation.

\subsection{CEM model}

Based on Eq. (12) and data in the period of 1961-1983, $\varepsilon_{1}$ and $\varepsilon_{2}$ were separately set as 2.12 and -2.25 by the leastsquare estimation. Then the model was applied to simulate the annual $Q$ during the period of 1961-2008. The difference of $Q$ between the simulation period of 1984-2008 and the reference period of 1961-1983 was attributed to the impact of climate variation. Simulated annual $Q$ values were 57.7 and $42.6 \mathrm{~mm}$ during the periods of 1984-1999 and 

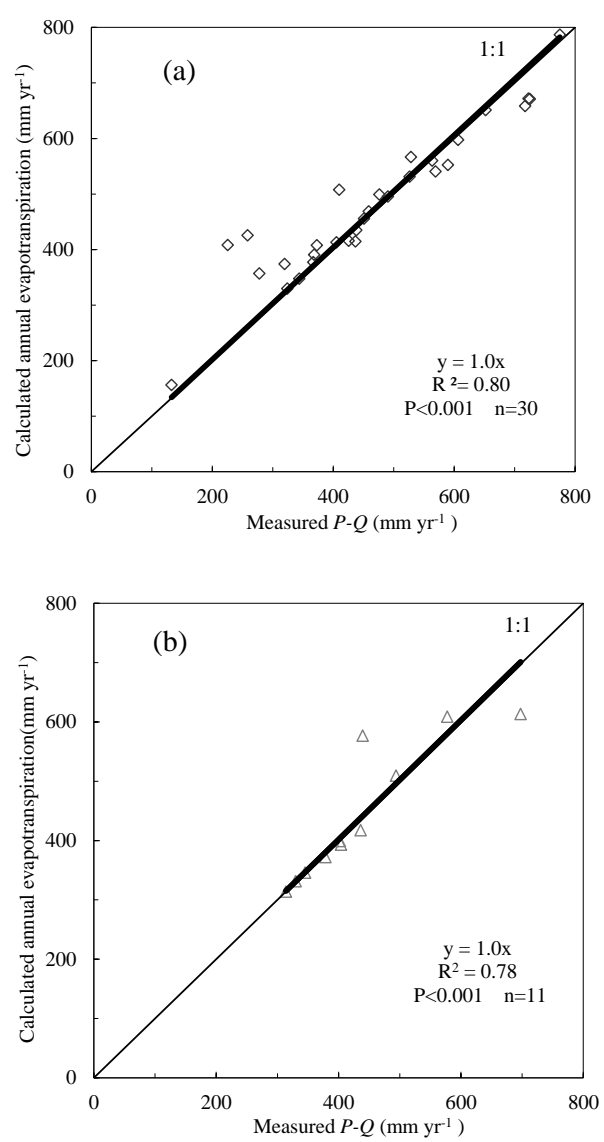

Figure 8. Scatterplots of calculated evapotranspiration using Eqs. (7) and (8) against $E_{\mathrm{a}}=P-Q$ during the calibration phase (a) and validation period (b). The thin line is the $1: 1$ line, and the bold line is the line of best fit provided by the equation.

2000-2008, respectively. The contribution of climate variation to the decrease of inflow during these two periods is about $1.5 \mathrm{~mm}(8 \%)$ and $16.5 \mathrm{~mm}(42 \%)$, respectively. Correspondingly, land use change contributed $16.6 \mathrm{~mm}(92 \%)$ and $23.2 \mathrm{~mm}(58 \%)$ to the decrease of inflow (Table 1$)$.

\subsection{RRM model}

Using annual $P$ and the variance of the monthly $P$ from 1961 to 1983 , the values of $a, b$, and $c$ were obtained as 0.85 , 0.0004 , and 0.74 from Eq. (16), respectively. Then annual inflow into the reservoir was simulated as 56.4 and $33.8 \mathrm{~mm}$ for evaluation period I and II, respectively. Derived from Eq. (17), climate variation constituted $2.7 \mathrm{~mm}(15 \%)$ and $25.3 \mathrm{~mm} \mathrm{(64 \% )} \mathrm{of} \mathrm{total} Q$ decrease for these two periods (Table 1). Compared to estimations from the CEM model, the contribution of climate variations to the decrease of inflow was about $7 \%$ higher during the period of 1984-1999, but $22 \%$ lower during the period of 2000-2008.

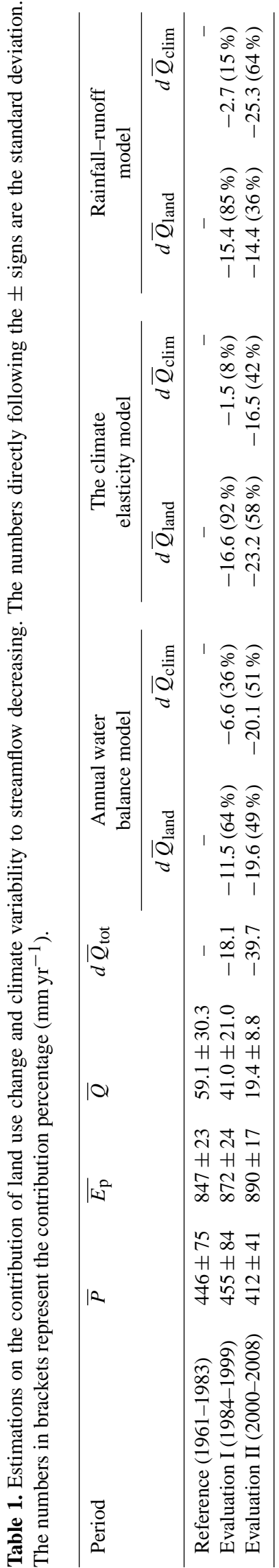

Hydrol. Earth Syst. Sci., 20, 1561-1572, 2016 


\section{Discussion}

\subsection{Data limitation and likely impact of other human factors on streamflow}

This study spans multiple years and uses multiple data sources for land use, meteorology, and hydrology. Data bias often exists in field measurements, inventory, aggregation, and spatial analysis of long-series spatiotemporal data (Kavetski et al., 2006; Verburg et al., 2011). In the process of building the annual water balance model, 30 land use scenarios were utilized to calibrate the model and 11 land use scenarios were employed to verify it. To some extent, land use images were not comparable because the data were interpreted from different days of a year. Meanwhile, interpretation of remote-sensing imagery also increases the possibility of the errors. Only 37 rainfall gauges and 7 meteorological stations were available to clarify spatial change of precipitation and air temperature for a mountainous catchment with a drainage area of $15380 \mathrm{~km}^{2}$; thus interpolation errors may exist

Since the 1980s, water uses in the MYRC have been intensified due to the increased water demand by people (Bao et al., 2012a). On one hand, due to the growth of population (Fig. 2) and development of industry and agriculture, the annual direct water withdrawal from the MYRC increased from $2.2 \mathrm{~mm} \mathrm{yr}^{-1}$ in $1956-1983$ to $13.4 \mathrm{~mm} \mathrm{yr}^{-1}$ in $1984-2005$ (Ma et al., 2010). At the same time, daily water consumption per capita accrued from $0.03 \mathrm{~m}^{3}$ in 1959 to more than $0.20 \mathrm{~m}^{3}$ in 2000 (Gao et al., 2002). Population growth aggravates water scarcity because it reduces per capita availability even with unchanged water resources (Schewe et al., 2014). Meanwhile, soil and water conservation projects have been implemented considerably with slopes transformed into terraces, and the construction of silt retention dams and reservoirs in the 1970s and 1980s (Chaobai River Management Bureau of Beijing, 2004; Chang et al., 2015). For example, the Yunzhou Reservoir (113.7 million $\mathrm{m}^{3}$ ) and Baihebao Reservoir (90.6 million $\mathrm{m}^{3}$ ) were built in 1970 and 1983, respectively (Hydrological yearbook of the people's Republic of China, 1991). In addition to water consumption, these water control projects enhanced evaporation and leakage losses from the catchment (Gao et al., 2013). Consequently, total water loss from the catchment had increased since the 1980s. In recent years, the Paddy to Dry Land Project and programs of closing water-based industries have been carried out to reduce water consumption that might have compensated the streamflow decline trend and have improved water quality (Wang, 2010).

\subsection{Model uncertainties}

Three different approaches were used to isolate hydrological impacts of land use change from those of climate change. The AWB offered a direct approach to evaluate hydrolog- ical impacts of land use change (Zhang and Wang, 2007). $E_{\mathrm{a}}$, as the predominant part of the water cycle, is the key to build this model. It is attributed primarily to land use and also affected by several other factors such as soil types and topographic slope (Moiwo et al., 2010). The daily $E_{\mathrm{a}}$ $\left(\mathrm{mm} \mathrm{day}^{-1}\right)$ might be improved by the Surface Energy Balance Algorithm for Land (SEBAL), remote-sensing-based models validated by the Penman-Monteith approach, and the SWAT model (Gao and Long, 2008; Gao et al., 2008). The Penman-Monteith method is commonly considered as the best way to estimate the value of $E_{\mathrm{p}}$. However, the application was difficult due to insufficient climate data, especially variables about solar radiation. Therefore, the Hamon method (Hamon, 1963) recommended by the Food and Agriculture Organization of the United Nations (FAO) was used to calculate $E_{\mathrm{p}}$. The model parameter $(\omega)$ had been derived from numerous catchments (Zhang et al., 2001). Then a simple two-parameter model based on these coefficients was applied to many other catchments (Sun et al., 2005; Ma et al., 2008; Zhang et al., 2008). Our research specified an analytical expression to determine the value of 2.8 and 1.5 , respectively, for forestland and grassland/cropland with a correlation coefficient of 0.78 and 0.80 during calibration and validation phases, respectively. The data errors combined with uncertainty of model structure increased uncertainty to attribution of land use change. Meanwhile, to detect the potential streamflow response of land use change in the MYRC, the model adopted the land use data in 1988 to estimate streamflow since 1984, which may cause errors due to variation of land use from 1984 to 1988 . Besides, spatial and temporal variations of land use also affected streamflow change (Donohue et al., 2011; Roderick and Farquhar, 2011). In the model, recharge to groundwater and change of soil water storage might be ignored for water balance in a meso-scale catchment (Sun et al., 2005). Moreover, uncertainty of the model would be exaggerated when applied to small catchments, such as the BCZ catchment $\left(65.2 \mathrm{~km}^{2}\right)$ and the TM catchment $\left(3.4 \mathrm{~km}^{2}\right)$.

In the CEM, $P$ and $E_{\mathrm{p}}$ were employed to assess hydrological impacts of climate variation. Annual $P$ in the evaluation period I was $9 \mathrm{~mm} \mathrm{yr}^{-1}$ more than that in the reference period. Simultaneously, $E_{\mathrm{p}}$ in the evaluation period I was $25 \mathrm{~mm} \mathrm{yr}^{-1}$ more than that in the reference period. $d \bar{Q}_{\text {clim }}$ was only $-1.5 \mathrm{~mm} \mathrm{yr}^{-1}$, which indicated that the $Q$ increment as the result of the $P$ increment was slightly less than $Q$ reduction as the result of the $E_{\mathrm{p}}$ increment.

As a quantitative assessment on hydrological impacts of climate change, without spatial input, especially for the catchment area of $15380 \mathrm{~km}^{2}$ with altitude range from 50 to $2292 \mathrm{~m}$ (Fig. 1), the climate elasticity model lacks physical mechanisms and ignores the spatial details of the impact of climate variation (Yang et al., 2014a). The relative error increases with a median of $3.0 \%$ and a maximum of $20 \%$ with 
a $10 \%$ precipitation alteration in moutains in China (Yang et al., 2014b).

The RRM accounts for rainfall as the only climatic indicator to estimate the impact of climate change. This simplification might be the main reason resulting in the differences from other two approaches. $P$ for 1984-1999 was $9 \mathrm{~mm} \mathrm{yr}^{-1}$ greater than that for $1961-1983$, while $d \bar{Q}_{\text {clim }}$ was $2.7 \mathrm{~mm} \mathrm{yr}^{-1}$ smaller correspondingly (Table 1), which illustrated that the variance of the monthly precipitation played an important role in modeling streamflow besides annual $P$. Moreover, the watershed in the Miyun Reservior was characterized by thin soils $(<30 \mathrm{~cm})$ in a rocky mountain environment (He et al., 2010). Therefore, the watershed is rather responsive to rainfall events.

\subsection{Implications to water resources management}

In the Miyun Reservoir catchment, forestlands accounted for more than half of the total area. Compared to 1978, forestland area increased by $5.0 \%$ in $1988,16.3 \%$ in 1998 , and $18.2 \%$ in 2008 , whereas cropland decreased by $6.6,8.7$, and $10.8 \%$, respectively. Meanwhile, grassland area increased from $16.5 \%$ in 1978 to $18.5 \%$ in 1988 , and then reduced to $10.4 \%$ in 1998, and $9.8 \%$ in 2008 (Fig. 9). Compared to the reference period, land use change resulted in streamflow decline for the 1984-1999 and 2000-2008 periods. It appears that the land use change effect was most pronounced during 1984-1999. Since January 1982, implementation of the household contract responsibility system has brought a huge impact on cropland and forestland. Reforestation has been widely implemented to develop forest industry and tourism especially along with implementation of Grain for Green and the Beijing-Tianjin Sandstorm Cource Control Project since the later 1990s (Zheng et al., 2010).

This study shows that the study region has experienced global warming, and climate change may increase the uncertainty of the estimated land use impact (Lauri et al., 2012). Climate change should be considered as a critical factor to optimize future water management (Gosling et al., 2011). Furthermore, anthropogenic effects, including water withdrawal and water restriction policy, could have both negative and positive effects on water supply to the Miyun Reservoir. Monitoring and objectively evaluating spatial and temporal variation of water resources are the prerequisites for water resource planning. Land use could also offset the negative effects of climate variation. For example, paddy-to-dry-land conversion in the study basin is considered as an effective means to increase inflow into the Miyun Reservoir. Moreover, artificial forest plantations widely implemented during the last 30 years are considered to aggravate water stress in this semi-arid region (Wang et al., 2012). More local vegetation rather than man-made forests with exotic tree species should be established to achieve the desired hydrological functioning of the MYRC. At the same time, proper allocation of water resources, such as water demand mangement,

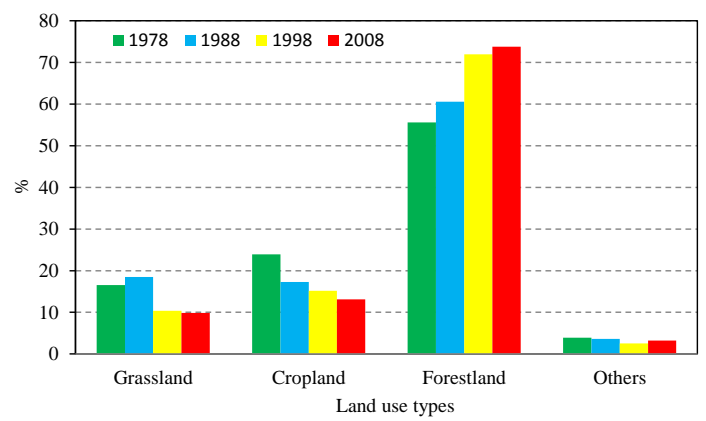

Figure 9. Land use composition of the Miyun Reservoir catchment $\left(14653 \mathrm{~km}^{2}\right)$ in $1978,1988,1998$, and 2008.

can play an important role in solving water crises. In summary, comprehensive measures including vegetation restoration and water allocation are necessary to deal with water shortages facing the MYRC.

\section{Conclusions}

The comprehensive modeling approach developed by this study offers insights into the hydrological changes in the Miyun Reserior, which has experienced a significant decreasing trend of streamflow in the past 3 decades due to a combination of changes in land use and climate. The dramatic change of land use in the 1980s and 1990s due to expansion of forestland and reduction of cropland has exacerbated streamflow decline by boosting catchment evapotransiration. Climate change during the 1990s-2000s has resulted in an increase in air temperature and thus poential evapotransiration, resulting in an increase in total water loss from the study basin. Land use change dominated the streamflow decline in the 1980s-1990s, but climate change contributed most to the water supply decline in the 2000s.

We conclude that future climate change must be considered in designing watershed management strategies including reforesation efforts to protect water quality and to reduce soil erosion in the Miyun Reservoir to meet the increasing water supply demand of the megacity of Beijing. Active land use management such as converting marginal croplands to natural grasslands, planting local species rather than exotic species, and water resources management such as irrigation or industry water uses should be optimized to adapt to future climate changes to sustain the water supply functions of the Miyun Reservior. Future studies should focus on sceanario analysis to examine the trade-offs of water management options in terms of hydrologic impacts under future climate change conditions.

Acknowledgements. This work was financially supported by the China Postdoctoral Science Foundation (no. 2012M511938), Forestry Nonprofit Industry Research of State Forestry Administration (No. 201104109), and China Scholarship Council for visiting 
Duke University. We thank Cunyong Ju for his assistance in data analysis.

Edited by: S. Uhlenbrook

\section{References}

Aguado, E., Cayan, D., Riddle, L., and Roos, M.: Climatic fluctuations and the timing of West Coast streamflow, J. Climate, 5, 1468-1483, 1992.

Arabi, M., Govindaraju, R. S., and Hantush, M. M.: A probabilistic approach for analysis of uncertainty in the evaluation of watershed management practices, J. Hydrol., 333, 459-471, 2007.

Baker, T. J. and Miller, S. N.: Using the Soil and Water Assessment Tool (SWAT) to assess land use impact on water resources in an East African watershed, J. Hydrol., 486, 100-111, 2013.

Bao, Z., Fu, G., Wang, G., Jin, J., He, R., Yan, X., and Liu, C.: Hydrological projection for the Miyun Reservoir basin with the impact of climate change and human activity, Quatern. Int., 282, 96-103, doi:10.1016/j.quaint.2012.07.012, 2012a.

Bao, Z., Zhang, J., Wang, G., Fu, G., He, R., Yan, X., Jin, J., Liu, Y., and Zhang, A.: Attribution for decreasing streamflow of the Haihe River basin, northern China: Climate variability or human activities?, J. Hydrol., 460-461, 117-129, doi:10.1016/j.jhydrol.2012.06.054, 2012b.

Barnett, T. P., Adam, J. C., and Lettenmaier, D. P.: Potential impacts of a warming climate on water availability in snow-dominated regions, Nature, 438, 303-309, 2005.

Beguería, S., López-Moreno, J. I., Lorente, A., Seeger, M., and García-Ruiz, J. M.: Assessing the effect of climate oscillations and land-use changes on streamflow in the Central Spanish Pyrenees, Ambio, 32, 283-286, 2003.

Brown, A. E., Zhang, L., McMahon, T. A., Western, A. W., and Vertessy, R. A.: A review of paired catchment studies for determining changes in water yield resulting from alterations in vegetation, J. Hydrol., 310, 28-61, doi:10.1016/j.jhydrol.2004.12.010, 2005.

Chang, J., Zhang, H., Wang, Y., and Zhu, Y.: Assessing the impact of climate variability and human activity to streamflow variation, Hydrol. Earth Syst. Sci. Discuss., 12, 5251-5291, doi:10.5194/hessd-12-5251-2015, 2015.

Chaobai River Management Bureau of Beijing: Flood and Drought Hazards in the Chaobai River, China Water Resour. and Hydropow. Press, Beijing, 1-209, 2004.

Christensen, N. S., Wood, A. W., Voisin, N., Lettenmaier, D. P., and Palmer, R. N.: The effects of climate change on the hydrology and water resources of the Colorado River basin, Climatic Change, 62, 337-363, 2004.

Costa, M. H., Botta, A., and Cardille, J. A.: Effects of largescale changes in land cover on the discharge of the Tocantins River, Southeastern Amazonia, J. Hydrol., 283, 206-217, doi:10.1016/s0022-1694(03)00267-1, 2003.

Dong, W. and Li, X.: Analysis of water resource of Miyun reservoir in Chaobai river basin, Environ. Sci. Technol., 29, 58-60, 2006.

Donohue, R. J., Roderick, M. L., and McVicar, T. R.: Can dynamic vegetation information improve the accuracy of Budyko's hydrological model?, J. Hydrol., 390, 23-34, 2010.
Donohue, R. J., Roderick, M. L., and McVicar, T. R.: Assessing the differences in sensitivities of runoff to changes in climatic conditions across a large basin, J. Hydrol., 406, 234-244, doi:10.1016/j.jhydrol.2011.07.003, 2011.

Fu, G., Charles, S. P., and Chiew, F. H. S.: A two-parameter climate elasticity of streamflow index to assess climate change effects on annual streamflow, Water Resour. Res., 43, W11419, doi:10.1029/2007WR005890, 2007.

Gao, P., Geissen, V., Ritsema, C. J., Mu, X. M., and Wang, F.: Impact of climate change and anthropogenic activities on stream flow and sediment discharge in the Wei River basin, China, Hydrol. Earth Syst. Sci., 17, 961-972, doi:10.5194/hess-17-9612013, 2013.

Gao, Y. and Long, D.: Intercomparison of remote sensing-based models for estimation of evapotranspiration and accuracy assessment based on SWAT, Hydrol. Process., 22, 4850-4869, doi:10.1002/hyp.7104, 2008.

Gao, Y., Yao, Z., Liu, B., and Lv, A.: Evolution trend of Miyun Reservoir inflow and its motivation factors analysis, Prog. Geogr., 21, 546-553, 2002.

Gao, Y., Long, D., and Li, Z. L.: Estimation of daily actual evapotranspiration from remotely sensed data under complex terrain over the upper Chao river basin in North China, Int. J. Remote Sens., 29, 3295-3315, doi:10.1080/01431160701469073, 2008.

Gosling, S. N., Taylor, R. G., Arnell, N. W., and Todd, M. C.: A comparative analysis of projected impacts of climate change on river runoff from global and catchment-scale hydrological models, Hydrol. Earth Syst. Sci., 15, 279-294, doi:10.5194/hess-15279-2011, 2011.

Hamon, W. R.: Computation of direct runoff amounts from storm rainfall, Int. Assoc. Scient. Hydrol. Publ., 63, 52-62, 1963.

Haverkamp, S., Fohrer, N., and Frede, H. G.: Assessment of the effect of land use patterns on hydrologic landscape functions: a comprehensive GIS-based tool to minimize model uncertainty resulting from spatial aggregation, Hydrol. Process., 19, 715727, doi:10.1002/hyp.5626, 2005.

He, J., Cai, Q., Li, G., and Wang, Z.: Integrated erosion control measures and environmental effects in rocky mountainous areas in northern China, Int. J. Sediment Res., 25, 294-303, doi:10.1016/s1001-6279(10)60046-7, 2010.

Hydrological yearbook of the people's Republic of China: the Haihe River Basin, Hebei Province Hydrologic Station Press, Shijiazhuang, 3, 144-150, 1991.

Isik, S., Kalin, L., Schoonover, J. E., Srivastava, P., and Lockaby, B. G.: Modeling effects of changing land use/cover on daily streamflow: An Artificial Neural Network and curve number based hybrid approach, J. Hydrol., 485, 103-112, 2013.

Jones, R. N., Chiew, F. H. S., Boughton, W. C., and Zhang, L.: Estimating the sensitivity of mean annual runoff to climate change using selected hydrological models, Adv. Water Resour., 29, 1419-1429, doi:10.1016/j.advwatres.2005.11.001, 2006.

Kavetski, D., Kuczera, G., and Franks, S. W.: Bayesian analysis of input uncertainty in hydrological modeling: 2. Application, Water Resour. Res., 42, W03408, doi:10.1029/2005WR004376, 2006.

Kim, J., Choi, J., Choi, C., and Park, S.: Impacts of changes in climate and land use/land cover under IPCC RCP scenarios on streamflow in the Hoeya River Basin, Korea, Sci. Total Environ., 452-453, 181-195, 2013. 
Lauri, H., deMoel, H., Ward, P. J., Räsänen, T. A., Keskinen, M., and Kummu, M.: Future changes in Mekong River hydrology: impact of climate change and reservoir operation on discharge, Hydrol. Earth Syst. Sci., 16, 4603-4619, doi:10.5194/hess-164603-2012, 2012.

Li, L., Zhang, L., Wang, H., Wang, J., Yang, J., Jiang, D., Li, J., and Qin, D.: Assessing the impact of climate variability and human activities on streamflow from the Wuding River basin in China, Hydrol. Process., 21, 3485-3491, doi:10.1002/hyp.6485, 2007.

$\mathrm{Li}, \mathrm{Z}$. and Li, X.: Trend and causation analysis of runoff variation in the upper reach of Chaobaihe River Basin in northern China during 1961-2005, J. Beijing Forest. Univ., 30, 82-87, 2008.

Liu, B., Yao, Z., and Gao, Y.: Trend and driving forces of water consumed structure changes in Beijing, Resource Science, 25, 38-43, 2003.

López-Moreno, J. I., Vicente-Serrano, S. M., Moran-Tejeda, E., Zabalza, J., Lorenzo-Lacruz, J., and García-Ruiz, J. M.: Impact of climate evolution and land use changes on water yield in the ebro basin, Hydrol. Earth Syst. Sci., 15, 311-322, doi:10.5194/hess15-311-2011, 2011.

Lu, J., Sun, G., McNulty, S., and Amatya, D. M.: A Comparison of Six Potential Evapotranspiration Methods for Regional Use in the Southeastern United States, J. Am. Water Resour. Assoc., 41, 621-633, 2005.

Ma, H., Yang, D., Tan, S. K., Gao, B., and Hu, Q.: Impact of climate variability and human activity on streamflow decrease in the Miyun Reservoir catchment, J. Hydrol., 389, 317-324, doi:10.1016/j.jhydrol.2010.06.010, 2010.

Ma, Z., Kang, S., Zhang, L., Tong, L., and Su, X.: Analysis of impacts of climate variability and human activity on streamflow for a river basin in arid region of northwest China, J. Hydrol., 352, 239-249, doi:10.1016/j.jhydrol.2007.12.022, 2008.

Mango, L. M., Melesse, A. M., McClain, M. E., Gann, D., and Setegn, S. G.: Land use and climate change impacts on the hydrology of the upper Mara River Basin, Kenya: results of a modeling study to support better resource management, Hydrol. Earth Syst. Sci., 15, 2245-2258, doi:10.5194/hess-15-22452011, 2011.

Mann, H. B.: Nonparametric tests against trend, Econometrica, 13, 245-259, doi:10.2307/1907187, 1945.

Mao, D. and Cherkauer, K. A.: Impacts of land-use change on hydrologic responses in the Great Lakes region, J. Hydrol., 374, 71-82, doi:10.1016/j.jhydrol.2009.06.016, 2009.

Moiwo, J. P., Lu, W., Zhao, Y., Yang, Y., and Yang, Y.: Impact of land use on distributed hydrological processes in the semi-arid wetland ecosystem of Western Jilin, Hydrol. Process., 24, 492503, 2010

Morán-Tejeda, E., Ceballos-Barbancho, A., and Llorente-Pinto, J. M.: Hydrological response of Mediterranean headwaters to climate oscillations and land-cover changes: The mountains of Duero River basin (Central Spain), Global Planet. Change, 72, 39-49, 2010.

Petchprayoon, P., Blanken, P. D., Ekkawatpanit, C., and Hussein, K.: Hydrological impacts of land use/land cover change in a large river basin in central-northern Thailand, Int. J. Climatol., 30, 1917-1930, 2010.

Raymond, P. A., Oh, N.-H., Turner, R. E., and Broussard, W.: Anthropogenically enhanced fluxes of water and carbon from the Mississippi River, Nature, 451, 449-452, 2008.
Risbey, J. S. and Entekhabi, D.: Observed Sacramento Basin streamflow response to precipitation and temperature changes and its relevance to climate impact studies, J. Hydrol., 184, 209223, 1996.

Roderick, M. L. and Farquhar, G. D.: A simple framework for relating variations in runoff to variations in climatic conditions and catchment properties, Water Resour. Res., 47, W00G07, doi:10.1029/2010WR009826, 2011.

Sankarasubramanian, A., Vogel, R. M., and Limbrunner, J. F.: Climate elasticity of streamflow in the United States, Water Resour. Res., 37, 1771-1781, doi:10.1029/2000wr900330, 2001.

Schaake, J. C. and Waggoner, P.: From climate to flow, Climate change and US water resources, John Wiley and Sons Inc., New York, 177-206, 1990.

Schewe, J., Heinke, J., Gerten, D., Haddeland, I., Arnell, N. W., Clark, D. B., Dankers, R., Eisner, S., Fekete, B. M., ColonGonzalez, F. J., Gosling, S. N., Kim, H., Liu, X., Masaki, Y., Portmann, F. T., Satoh, Y., Stacke, T., Tang, Q., Wada, Y., Wisser, D., Albrecht, T., Frieler, K., Piontek, F., Warszawski, L., and Kabat, P.: Multimodel assessment of water scarcity under climate change, P. Natl. Acad. Sci. USA, 111, 3245-3250, doi:10.1073/pnas.1222460110, 2014.

Searcy, J. K. and Hardison, C. H.: Double-mass curves Manual of Hydrology: Part 1. General surface-water Techniques, Geological survey water-supply paper 1541-B, United States Government Printing Office, Washington, D.C., 31-64, 1960.

Shen, Z. Y., Chen, L., and Chen, T.: Analysis of parameter uncertainty in hydrological and sediment modeling using GLUE method: a case study of SWAT model applied to Three Gorges Reservoir Region, China, Hydrol. Earth Syst. Sci., 16, 121-132, doi:10.5194/hess-16-121-2012, 2012.

Sneyers, R.: Sur l'analyse statistique des séries d'observations, Secrétariat de l'Organisation Météorologique Mondiale, Geneva, 1-192, 1975.

Stohlgren, T. J., Chase, T. N., Pielke, R. A., Kittel, T. G., and Baron, J.: Evidence that local land use practices influence regional climate, vegetation, and stream flow patterns in adjacent natural areas, Global Change Biol., 4, 495-504, 1998.

Sun, G., McNulty, S. G., Lu, J., Amatya, D. M., Liang, Y., and Kolka, R. K.: Regional annual water yield from forest lands and its response to potential deforestation across the southeastern United States, J. Hydrol., 308, 258-268, doi:10.1016/j.jhydrol.2004.11.021, 2005.

Sun, G., Zhou, G., Zhang, Z., Wei, X., McNulty, S. G., and Vose, J. M.: Potential water yield reduction due to forestation across China, J. Hydrol., 328, 548-558, doi:10.1016/j.jhydrol.2005.12.013, 2006.

Sun, S., Chen, H., Ju, W., Song, J., Zhang, H., Sun, J., and Fang, Y.: Effects of climate change on annual streamflow using climate elasticity in Poyang Lake Basin, China, Theor. Appl. Climatol., 112, 169-183, 2013.

Tang, L., Yang, D., Hu, H., and Gao, B.: Detecting the effect of land-use change on streamflow, sediment and nutrient losses by distributed hydrological simulation, J. Hydrol., 409, 172-182, doi:10.1016/j.jhydrol.2011.08.015, 2011.

Velázquez, J. A., Schmid, J., Ricard, S., Muerth, M. J., Gauvin StDenis, B., Minville, M., Chaumont, D., Caya, D., Ludwig, R., and Turcotte, R.: An ensemble approach to assess hydrological models' contribution to uncertainties in the analysis of climate 
change impact on water resources, Hydrol. Earth Syst. Sci., 17, 565-578, doi:10.5194/hess-17-565-2013, 2013.

Verburg, P. H., Kathleen, N., and Linda, N.: Challenges in using land use and land cover data for global change studies, Global Change Biol., 17, 974-989, doi:10.1111/j.13652486.2010.02307.x, 2011.

Wang, G., Xia, J., and Chen, J.: Quantification of effects of climate variations and human activities on runoff by a monthly water balance model: A case study of the Chaobai River basin in northern China, Water Resour. Res., 45, W00A11, doi:10.1029/2007wr006768, 2009.

Wang, R., Kalin, L., Kuang, W., and Tian, H.: Individual and combined effects of land use/cover and climate change on Wolf Bay watershed streamflow in southern Alabama, Hydrol. Process., 28, 5530-5546, doi:10.1002/hyp.10057, 2014.

Wang, S., Zhang, Z., McVicar, T. R., Zhang, J., Zhu, J., and Guo, J.: An event-based approach to understanding the hydrological impacts of different land uses in semi-arid catchments, J. Hydrol., 416-417, 50-59, doi:10.1016/j.jhydrol.2011.11.035, 2012.

Wang, S., Zhang, Z., McVicar, R. T., Guo, J., Tang, Y., and Yao, A.: Isolating the impacts of climate change and land use change on decadal streamflow variation: Assessing three complementary approaches, J. Hydrol., 507, 63-74, doi:10.1016/j.jhydrol.2013.10.018, 2013.

Wang, Y.: A spatiotemporal analysis of land use change and zoning of landscape restoration and protection in Miyun Reservoir watershed, PhD thesis of Chinese Academy of Forestry, Beijing, 38-39, 2010.

Wei, X., Liu, W., and Zhou, P.: Quantifying the relative contributions of forest change and climatic variability to hydrology in large watersheds: a critical review of research methods, Water, 5, 728-746, doi:10.3390/w5020728, 2013.

Wigbout, M.: Limitation in the use of double-mass curves, J. Hydrol., 12, 132-138, 1973.

Xie, P., Chen, G., Li, D., and Zhu, Y.: Comprehensive diagnosis method of hydrologic time series change-point analysis, Water Resour. Pow., 23, 11-14, 2005.

Xu, Z. X., Pang, J. P., Liu, C. M., and Li, J. Y.: Assessment of runoff and sediment yield in the Miyun Reservoir catchment by using SWAT model, Hydrol. Process., 23, 3619-3630, doi:10.1002/hyp.7475, 2009.
Yang, H., Yang, D., and Hu, Q.: An error analysis of the Budyko hypothesis for assessing the contribution of climate change to runoff, Water Resour. Res., 50, 9620-9629, doi:10.1002/2014wr015451, 2014a.

Yang, H., Qi, J., Xu, X., Yang, D., and Lv, H.: The regional variation in climate elasticity and climate contribution to runoff across China, J. Hydrol., 517, 607-616, doi:10.1016/j.jhydrol.2014.05.062, 2014b.

Yang, Y. and Tian, F.: Abrupt change of runoff and its major driving factors in Haihe River Catchment, China, J. Hydrol., 374, 373383, doi:10.1016/j.jhydrol.2009.06.040, 2009.

Zégre, N., Skaugset, A. E., Som, N. A., McDonnell, J. J., and Ganio, L. M.: In lieu of the paired catchment approach: Hydrologic model change detection at the catchment scale, Water Resour. Res., 46, W11544, doi:10.1029/2009wr008601, 2010.

Zhan, C., Xu, Z., Ye, A., and Su, H.: LUCC and its impact on run-off yield in the Bai River catchment-upstream of the Miyun Reservoir basin, J. Plant Ecol., 4, 61-66, doi:10.1093/jpe/rtr003, 2011.

Zhang, J. and Wang, G.: Impacts of climate changes on hydrology and water resources, Science Press, Beijing, 188-189, 2007.

Zhang, L., Dawes, W. R., and Walker, G. R.: Response of mean annual evapotranspiration to vegetation changes at catchment scale, Water Resour. Res., 37, 701-708, doi:10.1029/2000wr900325, 2001.

Zhang, X., Zhang, L., Zhao, J., Rustomji, P., and Hairsine, P.: Responses of streamflow to changes in climate and land use/cover in the Loess Plateau, China, Water Resour. Res., 44, W00A07, doi:10.1029/2007wr006711, 2008.

Zheng, J., Yu, X., Jia, G., and Xia, B.: Dynamic evolution of ecological service value based on LUCC in Miyun Reservoir Catchment, T. CSAE, 26, 315-320, 2010.

Zheng, J., Yu, X., Deng, W., Wang, H., and Wang, Y.: Sensitivity of land-use change to streamflow in Chaobai river basin, J. Hydrol. Eng., 18, 457-464, doi:10.1061/(asce)he.1943-5584.0000669, 2013. 